\title{
JOSEPH OLDHAM
}

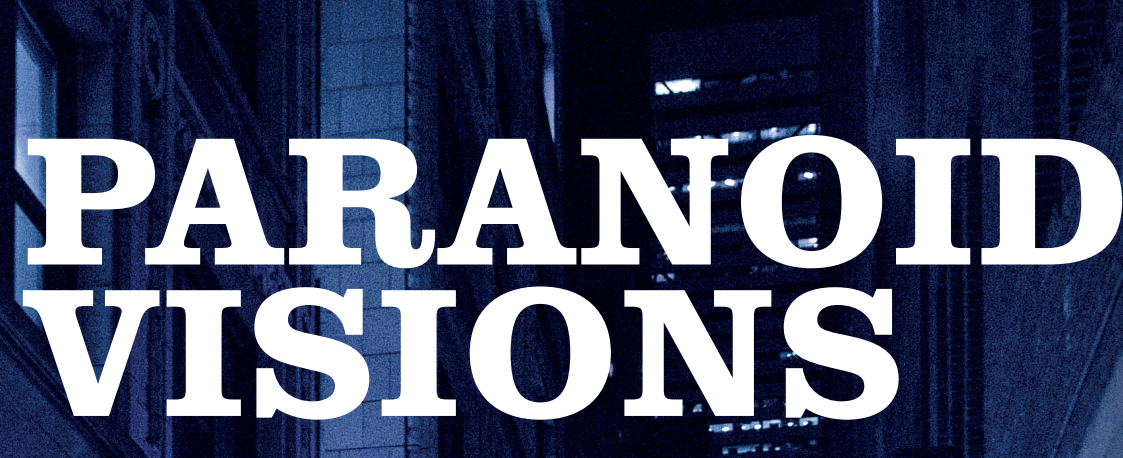

SPIES, CONSPIRACIES-AND THE SECRET STATE IN BRITISH TELEVISION DRAMA 


\section{Paranoid visions}

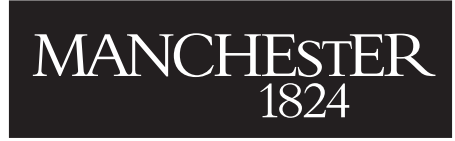

Manchester University Press 
Joseph Oldham - 9781526116130

Downloaded from manchesterhive.com at 04/26/2023 11:40:26AM 


\title{
Paranoid visions Spies, conspiracies and the secret state in British television drama
}

\author{
Joseph Oldham
}

Manchester University Press 
Copyright (C) Joseph Oldham 2017

The right of Joseph Oldham to be identified as the author of this work has been asserted by him in accordance with the Copyright, Designs and Patents Act 1988.

Published by Manchester University Press

Altrincham Street, Manchester M1 7JA

www.manchesteruniversitypress.co.uk

British Library Cataloguing-in-Publication Data

A catalogue record for this book is available from the British Library

Library of Congress Cataloging-in-Publication Data applied for

ISBN 9781784994150 hardback

First published 2017

The publisher has no responsibility for the persistence or accuracy of URLs for any external or third-party internet websites referred to in this book, and does not guarantee that any content on such websites is, or will remain, accurate or appropriate.

Typeset by

Servis Filmsetting Ltd, Stockport, Cheshire 